\title{
THE USE OF QUERCETIN FOR SPECTROPHOTOMETRIC DETERMINATION OF SOME CNS ACTING DRUGS
}

\author{
F. A. Mohamed, S. A. Hussein, H. A. Mohamed and S. A. Ahmed \\ Department of Pharmaceutical Analytical Chemistry, Faculty of Pharmacy, Assiut University, \\ Assiut-71526, Egypt
}

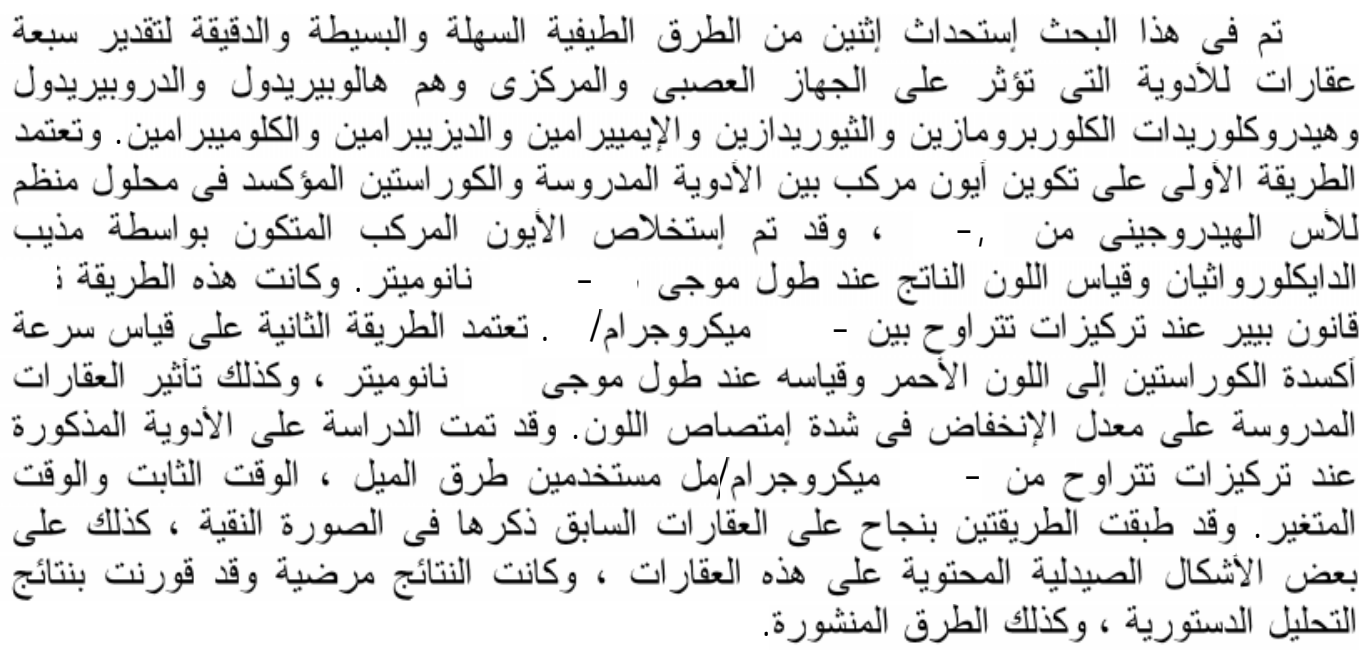

Two simple and sensitive spectrophotometric methods for the determination of seven CNS acting drugs namely; haloperidol, droperidol, chlorpromazine hydrochloride, thioridazine hydrochloride, imipramine hydrochloride, desipramine hydrochloride and clomipramine hydrochloride are presented. The first method is based on formation of an ion-pair complex between each of studied drugs and oxidized quercetin at $\mathrm{pH}$ range from 4.5 to 5.0. The colored complex formed was quantitatively extracted into dichloroethane, filtered over anhydrous sodium sulphate and then measured in the range of 528-534 nm. Beer's law was obeyed for all the studied drugs in the concentration range of $2-45 \mu \mathrm{g} / \mathrm{ml}$. The second method is a rapid kinetic method based on in-situ oxidation of quercetin into a red colored compound measured at $515 \mathrm{~nm}$. The rate of reaction between each of studied drugs and oxidized quercetin was followed by measuring the decrease in absorption intensity as a result of its reduction by each of the studied drugs. The studied compounds were determined in the concentration range of 5$50 \mu \mathrm{g} / \mathrm{ml}$ using slope, fixed time and variable time methods. The two methods were successfully applied to the analysis of studied drugs in the pure form and in commercial pharmaceuticals. The results were comparable with those obtained with either official or reported methods.

\section{INTRODUCTION}

The use of drugs with well demonestrated efficacy in psychiatric disorders has become wide spread since 1950s. Nowadays about $20 \%$ of prescriptions written in the United States are for medications intended for mental processes. ${ }^{1}$

Several analytical methods have been reported for determination of CNS acting drugs either in pure form or in their pharmaceutical preparations. These methods include; spectrophotometry, ${ }^{2-22}$ spectrofluorimetry, ${ }^{23-29}$ titrimetry, ${ }^{30-35}$ chromatography, ${ }^{36-48}$ flow injection analyses, ${ }^{49-53}$ radio-immunoassay, ${ }^{54-56}$ electrochemical methods ${ }^{57-58}$ and chemiluminescence methods. ${ }^{59-61}$

In the present work oxidized quercetin is used for extractive spectrophotometric 
determination of seven CNS acting drugs which are listed in Table 1. In addition oxidized quercetin is used also for kinetic spectrophotometric determination of five CNS acting drug, namely, chlorpromazine $\mathrm{HCl}$, thioridazine $\mathrm{HCl}$, clomipramine $\mathrm{HCl}$, imipramine $\mathrm{HCl}$ and desipramine $\mathrm{HCl}$. In our laboratory oxidized quercetin has been reported for determination of drugs containing tertiary amine and quaternary ammonium salt moieties. ${ }^{62}$ The use of quercetin as analytical reagent provides a fairly high extraction efficiency and sensitivity compared to other similar ion-pair reagents.

\section{EXPERIMENTAL}

\section{Instrumentation}

- A UV-1601, UV-Visible spectrophotometer (Shimadzu, Japan).

- pH-meter, model 3305 (Jenway, UK).

\section{Materials}

N- Bromosuccinimide (BDH, Poole, UK), quercetin (Merck, Darmstadt, Germany), haloperidol (\%purity 99.75 \pm 0.55 ) and droperidol (\%purity 99.21 \pm 0.43 ) (Gedeon Richter, Budapest, Hungary), imipramine $\mathrm{HCl}$ (\%purity 100.26 \pm 0.36 ), clomipramine $\mathrm{HCl}$ (\%purity 99.92 \pm 0.25 ) and desipramine $\mathrm{HCl}$ (\%purity 99.28 \pm 0.57 ) (Novartis Pharma AG, Basle, Switzerland), chlorpromazine $\mathrm{HCl}$ (\%purity 98.91 \pm 0.45 ) (May and Baker, England) and thioridazine $\mathrm{HCl}$ (\% \%urity 98.35 \pm 0.60 ) (Swiss Pharma, Cairo).
Pharmaceutical preparations containing studied drugs were obtained from local market. Halodol deconoas ${ }^{\circledR}$ ampoules (B.N. 97B24/247, Janssen Pharmaceutica, Beerse, Belgium), safinace $^{\circledR}$ tablets (1.5 mg B.N. 0010801, $5 \mathrm{mg}$ B.N. 0010651, Kahira, Cairo, Egypt), droperidol and desipramine (laboratory prepared synthetic mixtures), neurazine ${ }^{\circledR}$ tablets (B.N. 143021, Misr, Cairo, Egypt), promacid $^{\circledR}$ tablets (B.N. 15895, CID, Giza, Egypt), supranil ${ }^{\circledR}$ capsules $(25 \mathrm{mg}$ B.N. 01109127, 50 mg B.N. 91100194, ACAPI, Cairo, Egypt), melleril retard ${ }^{\circledR}$ tablets (200 mg B.N. 183, $30 \mathrm{mg}$ B.N. 118) tofranil $^{\circledR}$ tablets (B.N. 172) and anafranil ${ }^{\circledR}$ tablets $(25 \mathrm{mg}$ B.N.082, 75 mg B.N. 145) (Novartis Pharma AG, Basle, Switzerland).

- All other chemicals and solvents used in this work were of analytical grade.

\section{Reagents and solutions \\ NBS solution}

- Extractive spectrophotometric method. NBS solution $0.15 \% \mathrm{w} / \mathrm{v}$ in distilled water and was prepared fresh daily.

- Kinetic spectrophotometric method: For phenothiazines $3.0 \times 10^{-3} \mathrm{M}$ solution For dibenzazepines $7.2 \times 10^{-3} \mathrm{M}$ solution.

\section{Quercetin solution}

- Extractive spectrophotometric method. Quercetin solution $0.1 \% \mathrm{w} / \mathrm{v}$ in ethanol and was prepared fresh daily.

- Kinetic spectrophotometric method: For phenothiazines $3.0 \times 10^{-3} \mathrm{M}$ solution For dibenzazepines $7.2 \times 10^{-3} \mathrm{M}$ solution.

Table 1: Effect of different solvents on the absorption intensity and molar absorptivity of ion-pair complex of the studied drugs.

\begin{tabular}{|l|c|c|c|c|c|c|c|c|c||}
\hline \multirow{2}{*}{\multicolumn{1}{|c|}{ Solvent }} & \multicolumn{4}{|c|}{ Haloperidol $^{* * *}$} & \multicolumn{3}{c||}{ Chloropromazine $\mathrm{HCl}^{* *}$} & \multicolumn{3}{c||}{ Desipramine $\mathrm{HCl}^{* *}$} \\
\cline { 2 - 11 } & $\lambda_{\max }$ & Abs. & $\varepsilon_{\max }$ & $\lambda_{\max }$ & Abs. & $\varepsilon_{\max }$ & $\lambda_{\max }$ & Abs. $^{*}$ & $\varepsilon_{\max }$ \\
\hline Dichloroethane & 530 & 0.671 & 10088.3 & 532 & 0.625 & 8883 & 532 & 0.643 & 7789.3 \\
\hline Chloroform & 530 & 0.652 & 9817.7 & 532 & 0.614 & 8726.7 & 532 & 0.636 & 7704.5 \\
\hline Methylene chloride & 530 & 0.653 & 9817.9 & 532 & 0.617 & 8769.3 & 532 & 0.637 & 7716.6 \\
\hline Carbon tetrachloride & 290 & 0.038 & 511.3 & 295 & 0.042 & 596.9 & 305 & 0.049 & 593.6 \\
\hline Benzene & 516 & 0.178 & 2676.2 & 515 & 0.190 & 2700.4 & 513 & 0.193 & 233.8 \\
\hline
\end{tabular}

*Average of 4 determinations.

** Use $25 \mu \mathrm{g} / \mathrm{ml}$ from each drug. 


\section{Buffer solution}

Teorell and Stenhagen buffer pH 2.0-12.0 was prepared. ${ }^{63}$

\section{Standard drug solution}

Standard drug solutions were prepared by dissolving $50 \mathrm{mg}$ of the studied drug (as a salt) in $100 \mathrm{ml}$ of distilled water except haloperidol and droperidol were prepared by dissolving 50 $\mathrm{mg}$ of the base in $100 \mathrm{ml}$ methanol. Working standards covering the range $20-500 \mu \mathrm{g} / \mathrm{ml}$ were prepared by further dilutions.

\section{Preparation of sample \\ Tablets and capsules}

An accurately weighed amount of powder obtained from 20 tablets or capsules equivalent to $25 \mathrm{mg}$ of the drug was transferred into 100 $\mathrm{ml}$ volumetric flask which contain about $50 \mathrm{ml}$ distilled water (methanol in case of haloperidol and droperidol, then was shaked for 10 minutes, then was completed to $100 \mathrm{ml}$ with distilled water (methanol in case of haloperidol and droperidol), was filtered and first portion of filterate was rejected. The prepared solution was diluted quantitatively to obtain the required concentration for assay.

\section{Ampoules}

The content of 10 ampoules was mixed well and an accurately measured volume of the solution equivalent to $50 \mathrm{mg}$ of drug was quantitatively diluted with methanol to $100 \mathrm{ml}$. The resulting solution was diluted with methanol to obtain the required concentration for analysis.

\section{General assay procedure \\ Extractive spectrophotometric method}

One milliliter of standard drug solution was transferred into seperating funnel then 1 $\mathrm{ml}$ of buffer solution $\mathrm{pH} 5.0$ was added. An aliquot of $1 \mathrm{ml}$ of freshly prepared quercetin solution $0.1 \% \mathrm{w} / \mathrm{v}$ was added followed by $1 \mathrm{ml}$ of NBS solution $0.15 \% \mathrm{w} / \mathrm{v}$. The content was mixed well and shaked with two $10 \mathrm{ml}$ portions of dichlorethane then the organic solvent extracts were combined. The organic solvent extract was filtered over $2 \mathrm{~g}$ anhydrous sodium sulfate then the absorbance was measured at specified wavelength listed in Table 2 against a blank treated similarly using $1 \mathrm{ml}$ of drug solution solvent.

\section{Kinetic spectrophotometric method}

Two milliliters of quercetin solution was transferred into $50 \mathrm{ml}$ volumetric flask followed by $8 \mathrm{ml}$ of $\mathrm{N}$-bromosuccinimide solution, then allowed to stand for 10 minutes till complete reaction between quercetin and NBS solution, a suitable aliquot of the studied drug solution was added to the contents of the flask. The solution is diluted to the mark with methanol. The solution and reagent blank were placed in spectrophotometer and absorbance change of the solution at $515 \mathrm{~nm}$ was recorded and apply any one from three kinetic methods.

\section{Slope method}

The variation of absorbance with time $\Delta \mathrm{A} / \Delta \mathrm{t}$ is plotted versus the concentration of the drug.

\section{Fixed time method}

The absorbance difference $\Delta \mathrm{A}$ between 1 $\mathrm{min}$. and $30 \mathrm{~min}$. from initiation of reaction is plotted versus concentration of the drug.

3. Variable time method

The time required to decrease absorbance to 0.47 in case of phenothiazines or to 1.00 in case of dibenzazepines is measured for each concentration and inverse time $1 / t$ is plotted versus concentration of the drug.

\section{RESULTS AND DISCUSSION}

\section{Extractive spectrophotometric method $($ Method A)}

Ion-pair extraction method seems to be the most effective means for transferring the nitrogenous compounds from the aqueous phase to organic phase. The separated ion-pair complex could be determined colorimetrically. On the basis of the nature of quercetin and previous reports concerning its oxidation ${ }^{64}$ a suggestion for the reaction mechanism is shown in Scheme 1. Quercetin being a flavanol undergoes oxidation of pyrocatechol moiety in ring $\mathrm{B}$ in presence of mild oxidants to produce highly colored o-quinone derivative. Ionization of hydroxyl group of ring $\mathrm{C}$ most probably become easier than the other two phenolic hydroxyl group in ring A. Leading to anion formation then the anion interacts with protonated tertiary amine from the drug (chlorpromazine hydrochloride) to form the color ion-pair complex. 
Table 2: Quantitative parameters and statistical data for all the studied drugs using extractive spectrophotometric method.

\begin{tabular}{|c|c|c|c|c|c|c|c|c|}
\hline & $\begin{array}{l}\lambda_{\max } \\
(\mathrm{nm})\end{array}$ & $\begin{array}{c}\varepsilon_{\max } \\
\left(\mathrm{L} \mathrm{mol}^{-1} \mathrm{~cm}^{-1)}\right.\end{array}$ & $\begin{array}{c}\text { Linearity range } \\
\mu \mathrm{g} / \mathrm{ml}\end{array}$ & LOD & LOQ & $\begin{array}{l}\text { Slope } \\
\text { (SE) }\end{array}$ & $\begin{array}{l}\text { Intercept } \\
\text { (SE) }\end{array}$ & $\begin{array}{l}\text { Correlation } \\
\text { coefficient }\end{array}$ \\
\hline $\begin{array}{l}\text { 1- Chlorpromazine } \\
\text { hydrochloride }\end{array}$ & 532 & 8613.0 & $2-45$ & 0.796 & 2.654 & $\begin{array}{c}0.02095 \\
(0.00023)\end{array}$ & $\begin{array}{c}0.05994 \\
(0.00556)\end{array}$ & 0.9994 \\
\hline $\begin{array}{l}\text { 2- Thioridazine } \\
\text { hydrochloride }\end{array}$ & 528 & 9638.2 & $3-45$ & 1.069 & 3.563 & $\begin{array}{c}0.02046 \\
(0.00029)\end{array}$ & $\begin{array}{c}0.06647 \\
(0.00734)\end{array}$ & 0.9991 \\
\hline $\begin{array}{l}\text { 3- Clomipramine } \\
\text { hydrochloride }\end{array}$ & 534 & 10482.8 & $3-50$ & 1.137 & 3.791 & $\begin{array}{c}0.02060 \\
(0.000276)\end{array}$ & $\begin{array}{c}0.07170 \\
(0.00781)\end{array}$ & 0.9991 \\
\hline $\begin{array}{l}\text { 4- Imipramine } \\
\text { hydrochloride }\end{array}$ & 535 & 9950.0 & $2-45$ & 1.014 & 3.380 & $\begin{array}{c}0.02160 \\
(0.000299)\end{array}$ & $\begin{array}{c}0.0592 \\
(0.00730)\end{array}$ & 0.9990 \\
\hline $\begin{array}{l}5 \text { - Desipramine } \\
\text { hydrochloride }\end{array}$ & 532 & 7813.5 & $2-50$ & 1.091 & 3.638 & $\begin{array}{c}0.02078 \\
(0.000277)\end{array}$ & $\begin{array}{c}0.07025 \\
(0.00756)\end{array}$ & 0.9990 \\
\hline 6- Haloperidol & 530 & 9532.0 & $2-45$ & 0.891 & 2.970 & $\begin{array}{c}0.02370 \\
(0.00030)\end{array}$ & $\begin{array}{c}0.04847 \\
(0.00704)\end{array}$ & 0.9991 \\
\hline 7- Droperidol & 534 & 9334.0 & $2-45$ & 0.895 & 2.983 & $\begin{array}{c}0.02068 \\
(0.00025)\end{array}$ & $\begin{array}{c}0.06623 \\
(0.00617)\end{array}$ & 0.9992 \\
\hline
\end{tabular}

LOD: Limit of detection $\mu \mathrm{g} / \mathrm{ml}$

LOQ: Limit of quantitation $\mu \mathrm{g} / \mathrm{ml}$ 
<smiles>Cc1c(-c2ccc(O)c(O)c2)oc2cc(O)cc(O)c2c1=O</smiles>

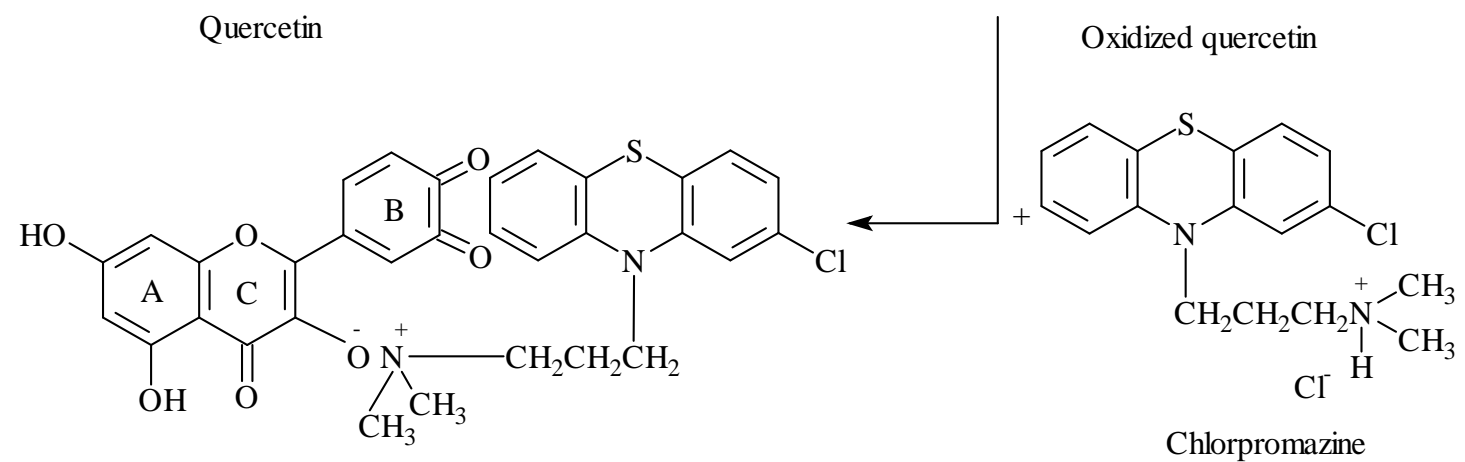

Ion-pair complex hydrochloride

\section{Scheme 1}

\section{Absorption spectra}

Quercetin is a yellow colored naturally occurring flavonoid (3,5,7,3',4'-pentahydroxy flavone). Upon oxidation using $\mathrm{N}$ bromosuccinimide a red colored product $\left(\lambda_{\max }=\right.$ $515 \mathrm{~nm}$ ) was produced immediately. Figure 1 shows absorption spectrum of oxidized quercetin.

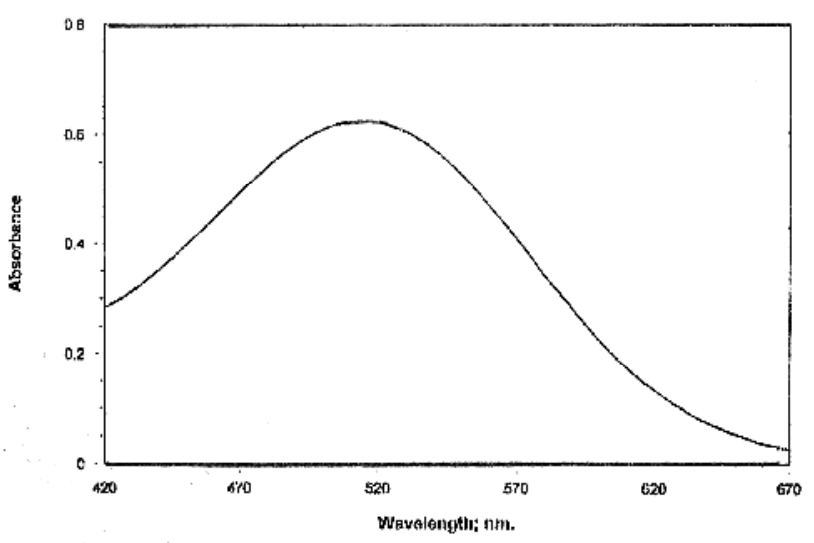

Fig. 1: Absorption spectrum of oxidized quercetin solution, $3 \times 10^{-3} \mathrm{M}$.

The oxidized quercetin reacts with the drug at $\mathrm{pH} 5.0$ to give highly colored ion-pair complex which is then extracted with dichloroethane and absorbance was measured at $530 \mathrm{~nm}$.
Figure 2 shows absorption spectrum of the formed ion-pair complex between oxidized quercetin and $25 \mu \mathrm{g} / \mathrm{ml}$ chlorpromazine $\mathrm{HCl}$.

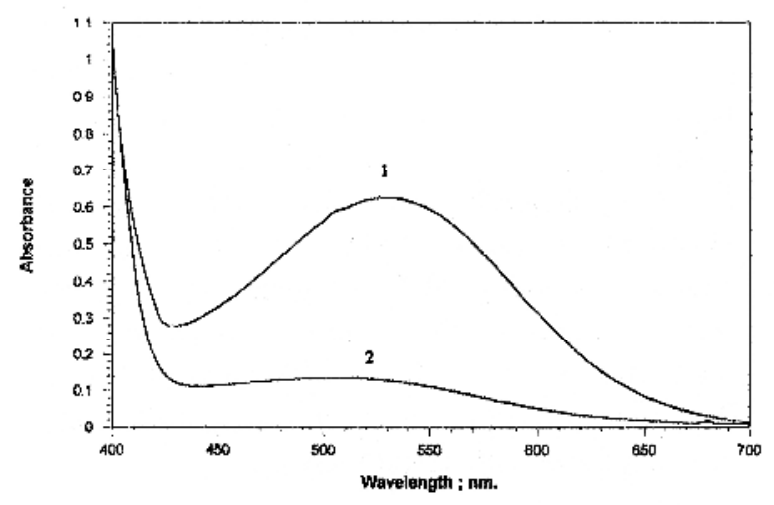

Fig. 2: Absorption spectra of an ion-pair complex of chlorpromazine $\mathrm{HCl}, 25 \mu \mathrm{g} / \mathrm{ml} \mathbf{1}$ and a reagent blandk of oxidized quercetin 2 .

\section{Optimization of variables for method A}

Various parameters affecting complexation and extraction processes were investigated and optimized for all the studied drugs.

\section{Effect of pH}

Effect of $\mathrm{pH}$ was studied by extraction of colored complexes formed in the presence of buffer solution at different $\mathrm{pH}$ values. Figure 3 shows the effect of $\mathrm{pH}$ on ion-pair complexes 
of studied drugs. It was found that maximum color intensity was obtained at $\mathrm{pH}$ 4.5-5.5 buffer solution of $\mathrm{pH} 5.0$ was selected for subsequent work. At higher $\mathrm{pH}$ values the oxidized quercetin becomes unstable and the reddish-violet color in aqueous phase changes to yellow. At lower $\mathrm{pH}$ values reagent blank gives relatively high readings.

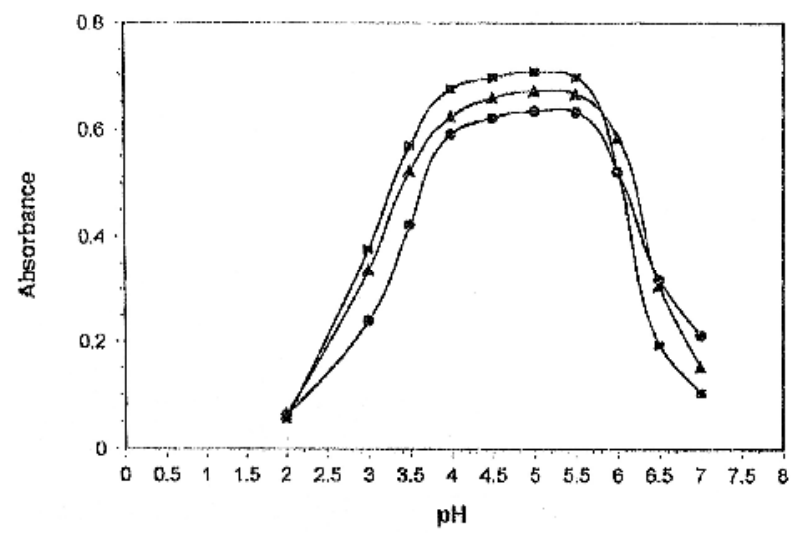

Fig. 3: Effect of $\mathrm{pH}$ on absorption intensity of the formed ion-pair complex using $25 \mu \mathrm{g} / \mathrm{ml}$ from $v$ Haloperidol, $\sigma$ Chlorpromazine HCL, $\lambda$ Desipramine $\mathrm{HCl}$.

\section{Effect of quercetin concentration}

Several solutions of quercetin in the concentration range from 0.02 to $0.2 \% \mathrm{w} / \mathrm{v}$ were prepared and $1 \mathrm{ml}$ from each solution was used for general assay procedure. The obtained absorbances were plotted against quercetin concentration (Fig. 4). The higher color intensity was obtained when using quercetin at concentration range from 0.08 to $0.14 \% \mathrm{w} / \mathrm{v}$. Therefore $0.1 \% \mathrm{w} / \mathrm{v}$ quercetin concentration was selected for all subsequent work.

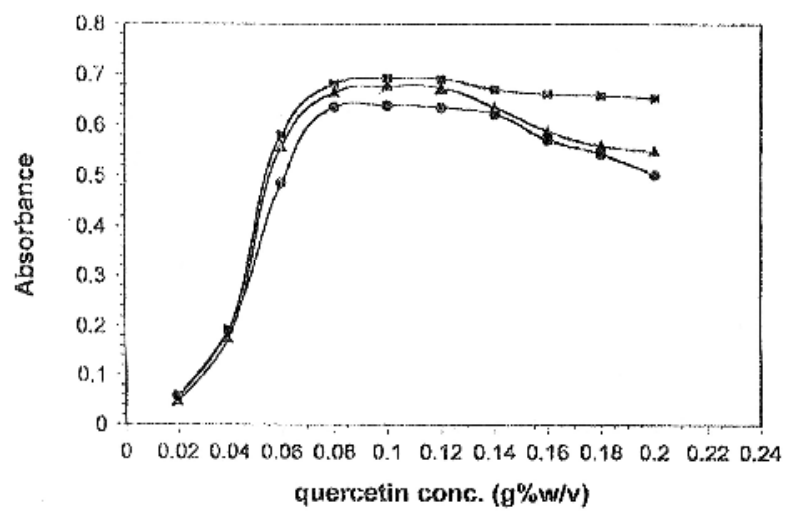

Fig. 4: Effect of quercetin concentration on absorption intensity of the formed ion-pair complex using $25 \mu \mathrm{g} / \mathrm{ml}$ from $v$ Haloperidol, $\sigma$ Chlorpromazine HCL, $\lambda$ Desipramine $\mathrm{HCl}$.

\section{Effect of NBS concentration}

Several concentrations of NBS solution in the concentration range 0.025 to $0.25 \% \mathrm{w} / \mathrm{v}$ were prepared and $1 \mathrm{ml}$ of each concentration was added to quercetin solution and procedure was completed as in general procedure. Figure 5 shows the effect of NBS concentration on absorption intensity. It shows that $0.15 \% \mathrm{w} / \mathrm{v}$ is the most suitable concentration for the determination of studied drugs. Concentrations greater than $0.175 \% \mathrm{w} / \mathrm{v}$ showed a marked decrease in absorption intensities which may be due to the further oxidation of quercetin to other products.

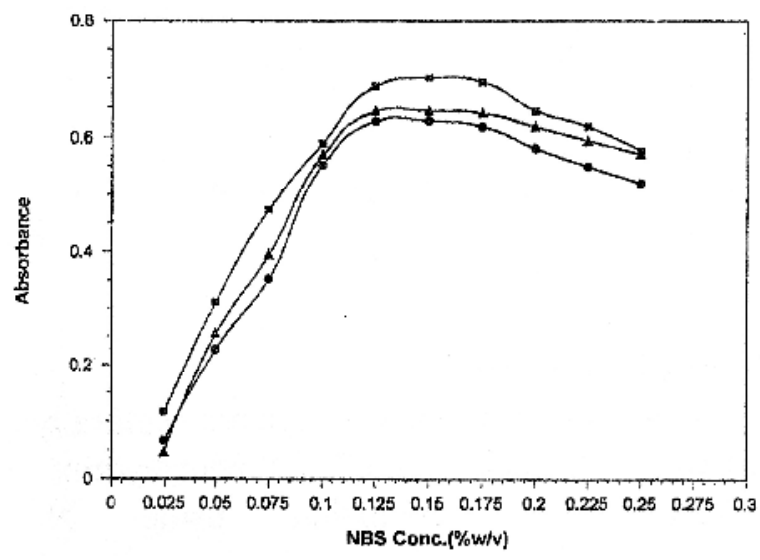

Fig. 5: Effect of NBS concentration on absorption intensity of the formed ion-pair complex using $25 \mu \mathrm{g} / \mathrm{ml}$ from $v$ Haloperidol, $\sigma$ Chlorpromazine HCL, $\lambda$ Desipramine $\mathrm{HCl}$.

\section{Effect of extraction solvent}

The formed ion-pair complex was extracted with different organic solvents such as 1,2-dichloroethane, methylene chloride, chloroform, benzene and carbon tetrachloride. Table 1 shows that the highest absorbances were obtained using dichloroethane as extraction solvent. Chloroform and methylene chloride could be used. Highly non-polar solvents such as carbon tetrachloride were found to have very poor extraction efficiency.

\section{Order of addition}

All possible sequences of addition of the reactants and buffer solutions were carried out. A significant decrease in the absorption intensity was noticed when both the drug and the oxidant NBS were added to each other and followed by addition of quercetin. This may be attributed to oxidation of the drug with NBS to 
give a compound which either does not react with oxidized quercetin or the formed ion-pair of this compound is poorly extracted into the organic phase. The most proper order was drug, buffer, quercetin and finally NBS.

\section{Effect of reaction and stability time}

Oxidation of quercetin by NBS was found to be rapid indicated by formation of reddish violet color in the aqueous phase. Figure 6 indicates the effect of reaction time on the absorption intensity of the formed ion-pair complexes of some studied drugs. It was found that the reaction between oxidized quercetin and the drug is very rapid (less than one min.). However after about $8 \mathrm{~min}$. reaction time a gradual decrease in the absorption intensity was observed. Regarding stability time of the colored products in dichloroethane it was noticed that the absorbances were slightly increased in the first $5 \mathrm{~min}$. and then remain stable for more than 1 hour. Results are shown in Figure 7.

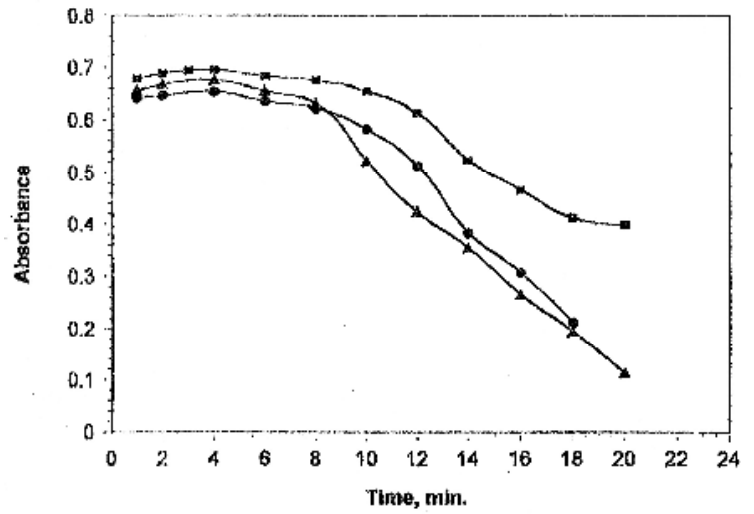

Fig. 6: Effect of reaction time on absorption intensity of the formed ion-pair complex using $25 \mu \mathrm{g} / \mathrm{ml}$ from $v$ Haloperidol, $\sigma$ Chlorpromazine HCL, $\lambda$ Desipramine $\mathrm{HCl}$.

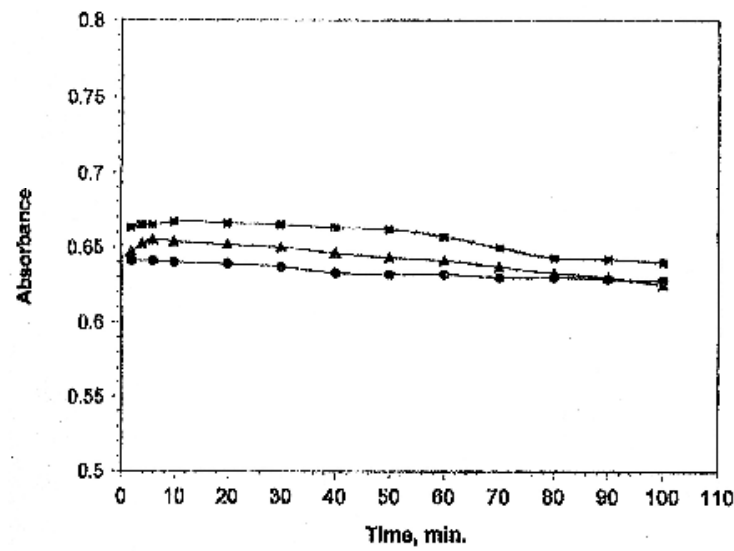

Fig. 7: Stability of the formed ion-pair complex using $25 \mu \mathrm{g} / \mathrm{ml}$ from $v$ Haloperidol, $\sigma$ Chlorpromazine HCL, $\lambda$ Desipramine $\mathrm{HCl}$.

\section{Analytical parameters}

Table 2 shows quantitiave parameters and statistical data for all the studied drugs. Slope (b) was used as a measure of sensitivity of the proposed method. Intercept (a) was used as a measure of interferring back ground. Five replicate determinations at different concentration levels were carried out to test precision of the method. The RSD was found to be less than $1.5 \%$ indicating reasonable repeatability of selected method. Regression analysis indicates excellent conformity with Beer's law over the concentration ranges listed in Table 2 for each drug.

\section{Interference study}

The effects of the presence of common tablet excepients such as; starch, sucrose, glucose, gum acacia, lactose, Mg-stearate and talc are studied. Results are listed in Table 3. Haloperidol was taken as a representative example. The results indicate that there is no interference from the frequently encountered excepients and additives. This is evidenced by the fact that all these additives are neutral and almost non extractable by organic solvents thus they do not contribute in the reaction at all. Also, the presence of traces of water in the organic solvent extracts may cause discrepancy in absorbance measurements and subsequent variation in results and so they must be removed by filteration over anhydrous sodium sulfate.

Table 3: Analysis of haloperidol $^{\circledR}$ as a representative example in the presence of some tablet excepients using method A.

\begin{tabular}{|l|c|c|}
\hline \multicolumn{1}{|c|}{ Ingredient } & $\begin{array}{c}\text { Amount } \\
\text { added }\end{array}$ & $\begin{array}{c}\text { \% Recovery } \\
\pm \text { S.D. }\end{array}$ \\
\hline 1- Starch & $50 \mathrm{mg}$ & $99.50 \pm 1.21$ \\
2- Sucrose & $50 \mathrm{mg}$ & $99.58 \pm 1.38$ \\
3- Glucose & $50 \mathrm{mg}$ & $99.4 \pm 1.25$ \\
4- Gum acacia & $10 \mathrm{mg}$ & $98.7 \pm 0.92$ \\
5- Lactose & $10 \mathrm{mg}$ & $98.4 \pm 1.11$ \\
6- Mg-stearate & $10 \mathrm{mg}$ & $99.1 \pm 1.08$ \\
7- Talc & $10 \mathrm{mg}$ & $98.7 \pm 1.3$ \\
\hline
\end{tabular}

*Average of five determinations.

${ }^{\circledR}$ Use $25 \mu \mathrm{g} / \mathrm{ml}$ of haloperidol 


\section{Kinetic Spectrophotometric method (Method B)}

Phenothiazines and diabenzazepines are able to reduce oxidized quercetin and decolorize it. Therefore, the rate of the reaction was determined through measurement of the decrease in absorbance at $515 \mathrm{~nm}$. (Figs. 8 and 9).

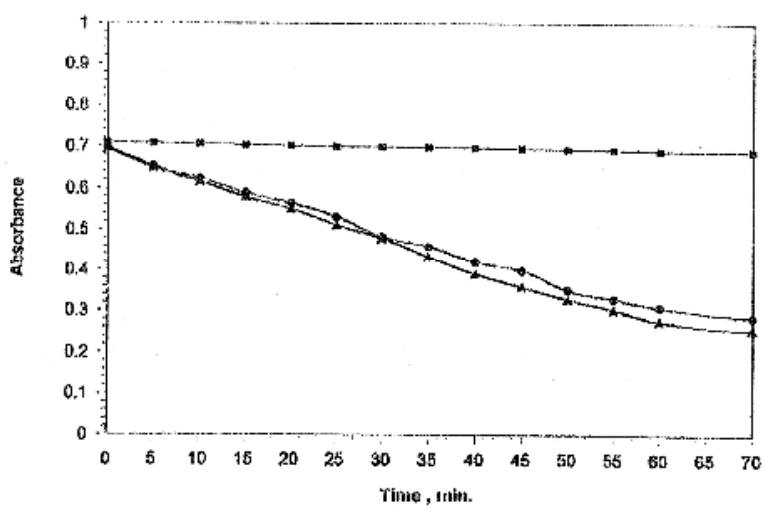

Fig. 8: Variation of absorbance of oxidized quercetin, $3 \times 10^{-3} \mathrm{M}$ with time upon addition of $30 \mu \mathrm{g} / \mathrm{ml}$. $v$ Without drug, $\sigma$ Chlorpromazine HCL, $\lambda$ Thioridazine $\mathrm{HCl}$.

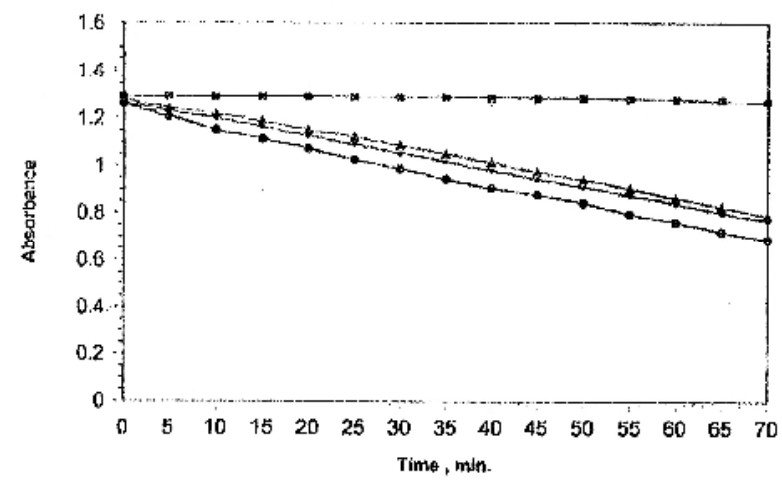

Fig. 9: Variation of absorbance of oxidized quercetin, $7.2 \times 10^{-3}$ with time upon addition of $30 \mu \mathrm{g} / \mathrm{ml}$. ^ Clomipramine $\mathrm{HCl}, \lambda$ Desipramine $\mathrm{HCl}, \sigma$ Imipramine $\mathrm{HCl}, v$ Without drug.

\section{Optimization of variables for method B}

Various parameters were investigated and optimized for all the studied drugs. All optimizations were carried out using fixed time kinetic method.

\section{Effect of temperature}

The temperature of $25^{\circ}$ was chosen as optimum temperature to carry out the reaction as oxidized quercetin is unstable at higher temperatures.

\section{Effect of oxidized quercetin concentration}

The molar ratio for the reaction of quercetin and NBS was determined using continuous variation method and 1:4 ratio was obtained; respectively. Following this different molar concentrations from quercetin and NBS were prepared $\left(0.6 \times 10^{-3} \mathrm{M}-10.8 \times 10^{-3} \mathrm{M}\right)$ keeping the ratio quercetin: NBS (1:4) then the procedure were completed as general procedure. The change in absorbance $\Delta \mathrm{A}$ was recorded and plotted against concentration of oxidized quercetin (Fig. 10). It was found that optimum concentration of oxidized quercetin for phenothiazines (chlorpromazine $\mathrm{HCl}$ and thioridazine $\mathrm{HCl}$ ) was $3.0 \times 10^{-3} \mathrm{M}$ and for dibenzazepine (clomipramine $\mathrm{HCl}$, imipramine $\mathrm{HCl}$ and desipramine $\mathrm{HCl}$ ) was $7.2 \times 10^{-3} \mathrm{M}$.

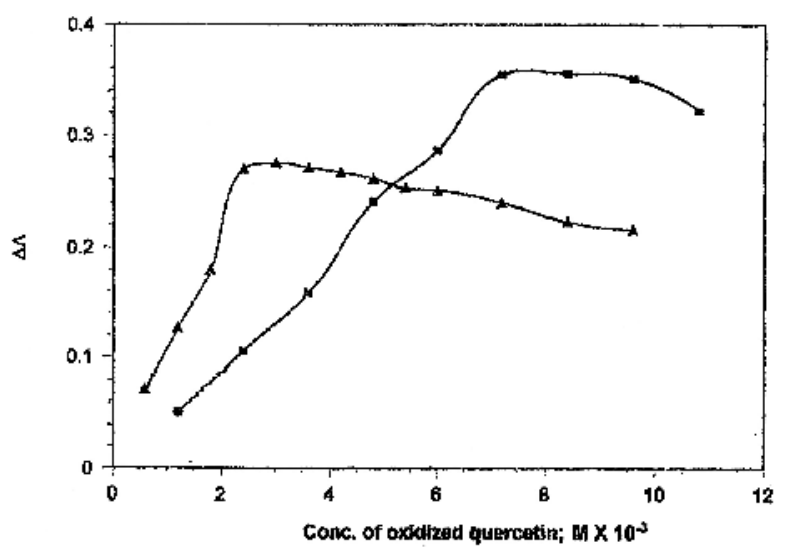

Fig. 10: Effect of oxidized quercetin concentration on absorption intensity difference caused by $30 \mu \mathrm{g} / \mathrm{ml}$ of $v$ Desipramine $\mathrm{HCl}, \sigma$ Chlorpromazine $\mathrm{HCl}$.

\section{Effect of dilution solvents}

Dilution of reaction mixture (quercetin, NBS and drug) with any of solvents listed in Table 4 showed slight effect on $\lambda$ max while the absorbance was affected. It was found that the highest absorption intensity was produced with methanol, therefore, it was used throughout this work.

\section{Effect of addition of acid or alkali}

To study effect of addition of acid or alkali one milliliter of $\mathrm{HCl}$ or $\mathrm{NaOH}$ solution range from $0.01 \mathrm{M}$ to $0.05 \mathrm{M}$ solution was added to reaction mixture. It was observed that the absorbance of oxidized quercetin decreased upon addition of acid or alkali. This attributed to that oxidized quercetin is unstable in acid or alkali. 
Table 4: Effect of dilution solvent on absorbance of oxidized quercetin after addition of studied drug.

\begin{tabular}{|l|l|c||c|c|}
\hline \multicolumn{1}{|c|}{ Solvent } & Abs. $^{*}$ & $\lambda_{\max }{ }^{*}$ & Abs. ${ }^{* *}$ & $\lambda_{\max }{ }^{* *}$ \\
\hline 1- Methanol & 0.695 & 515 & 1.298 & 515 \\
2- Ethanol & 0.632 & 515 & 1.259 & 515 \\
3- Water & 0.712 & 530 & 1.344 & 530 \\
4- Isopropyl alc. & 0.601 & 515 & 1.211 & 515 \\
5- Acetonitrile & 0.565 & 515 & 1.091 & 515 \\
6- 1,4-dioxan & 0.418 & 500 & 0.958 & 500 \\
\hline
\end{tabular}

"Using $30 \mu \mathrm{g} / \mathrm{ml}$ chlorpromazine $\mathrm{HCl}$ and $3 \times 10^{-3} \mathrm{M}$ oxidized quercetin.

*** Using $30 \mu \mathrm{g} / \mathrm{ml}$ desipramine $\mathrm{HCl}$ and $7.2 \times 10^{-3} \mathrm{M}$ oxidized quercetin.

\section{Kinetic data}

\section{- Slope method}

The method depends on plotting the reaction rate $\Delta \mathrm{A} / \Delta \mathrm{t}$ versus concentration of the studied drug.

\section{- Fixed time method}

The method depends on plotting the absorbance difference between absorbance after $1 \mathrm{~min}$. from beginning of reaction and absorbance after $30 \min . \Delta \mathrm{A}=\mathrm{A}_{1}=\mathrm{A}_{30}$ versus drug conceneration. This method was used for application on pharmaceutical preparations.

\section{- Variable time method}

The method depends on plotting $1 / \mathrm{t}$ reverse time required for absorbance to reach 0.47 for phenothiazines or 1.00 for dibenzazepines versus drug concentration. Table 5 shows the analytical data for determinaton of the studied drugs using different kinetic methods.

\section{Interference study}

Table 6 indicates that common tablet excepients did not interfere with the determination of the studied drugs. Among tablet excepients used in this study starch, sucrose, glucose, gum acacia, lactose, Mgstearate and talc. Interference study of these common tablet excepients on the determination of chlorpromazine $\mathrm{HCl}$ using fixed time kinetic method shows good recoveries indicating no interference.

\section{Analysis of pharmaceutical preparations}

Some commercial dosage forms of the studied drugs were successfully analyzed by the proposed methods and official or reported methods. Method A was extractive spectrophotometric method and Method B was kinetic method (using fixed time method for applications). Recovery experiments were performed for each drug in its dosage forms. The results are listed in Table 7 for all the studied drugs.

\section{Conclusion}

The proposed methods are simple, rapid, sensitive and accurate methods for analysis of some CNS acting drugs. The first method involves formation of an ion-pair complex between the drug and oxidized quercetin while in the second method the drug reduces oxidized quercetin. The two methods could be applied for routine analysis of studied drugs in pharmaceutical preparations without interference from common tablet excepients. 
Table 5: Quantitative parameters and statistical data for kinetic spectrophotometric method.

\begin{tabular}{|c|c|c|c|c|c|c|}
\hline Drug & $\begin{array}{l}\text { Linearity range } \\
\qquad(\mu \mathrm{g} / \mathrm{ml})\end{array}$ & $\begin{array}{l}\text { Slope } \\
\text { ( SE ) }\end{array}$ & $\begin{array}{l}\text { Intercept } \\
(\mathrm{SE})\end{array}$ & $\mathrm{r}$ & LOD & LOQ \\
\hline $\begin{array}{l}\text { 1- Chlorpromazine } \mathrm{HCl} \\
\text { i-Slope method }\end{array}$ & $5-50$ & 0.000179 & 0.002076 & 0.9990 & 1.431 & 4.771 \\
\hline ii- Fixed time method & $5-50$ & $\begin{array}{c}\left(2.75 \times 10^{-6}\right) \\
0.005183 \\
\left(7.75 \times 10^{-5}\right)\end{array}$ & $\begin{array}{c}\left(8.54 \times 10^{-5}\right) \\
0.060667 \\
(0.002403)\end{array}$ & 0.9991 & 1.391 & 4.636 \\
\hline $\begin{array}{l}\text { iii- Variable time } \\
\text { method }\end{array}$ & $5-45$ & $\begin{array}{r}0.000903 \\
\left(2.13 \times 10^{-5}\right) \\
\end{array}$ & $\begin{array}{c}0.007781 \\
(0.000599) \\
\end{array}$ & 0.9981 & 1.990 & 6.633 \\
\hline $\begin{array}{c}\text { 2- Thioridazine } \mathrm{HCl} \\
\text { i-Slope method }\end{array}$ & $5-50$ & 0.000191 & 0.001671 & 0.9979 & 2.136 & 7.120 \\
\hline & & $\left(4.38 \times 10^{-6}\right)$ & $(0.000136)$ & & & \\
\hline ii-Fixed time method & $5-50$ & 0.005545 & 0.048200 & 0.9981 & 1.990 & 6.633 \\
\hline iii-Variable time method & $5-50$ & $\begin{array}{c}0.001109 \\
\left(2.53 \times 10^{-5}\right)\end{array}$ & $\begin{array}{c}0.005883 \\
(0.000786)\end{array}$ & 0.9979 & 2.126 & 7.087 \\
\hline $\begin{array}{l}\text { 3- Desipramine } \mathrm{HCl} \\
\text { i-Slope method }\end{array}$ & $5-50$ & $\begin{array}{c}0.000304 \\
\left(6.53 \times 10^{-6}\right)\end{array}$ & $\begin{array}{l}-0.000380 \\
(0.000203)\end{array}$ & 0.9982 & 2.003 & 6.678 \\
\hline ii-Fixed time method & $5-50$ & $\begin{array}{c}0.008817 \\
(0.000190)\end{array}$ & $\begin{array}{c}-0.00118 \\
(0.005891)\end{array}$ & 0.9981 & 2.004 & 6.681 \\
\hline iii-Variable time method & $5-45$ & $\begin{array}{l}0.001079 \\
\left(2.3 \times 10^{-5}\right) \\
\end{array}$ & $\begin{array}{c}0.003741 \\
(0.000646) \\
\end{array}$ & 0.9984 & 1.796 & 5.987 \\
\hline $\begin{array}{l}\text { 4-Clomipramine } \mathrm{HCl} \\
\text { i-Slope method }\end{array}$ & $5-50$ & $\begin{array}{l}0.000295 \\
\left(5.7 \times 10^{-6}\right)\end{array}$ & $\begin{array}{c}-0.00032 \\
(0.000177)\end{array}$ & 0.9985 & 1.800 & 6.000 \\
\hline ii-Fixed time method & $5-50$ & $\begin{array}{c}0.008577 \\
(0.000149)\end{array}$ & $\begin{array}{l}-0.010470 \\
(0.004619)\end{array}$ & 0.9988 & 1.616 & 5.385 \\
\hline iii-Variable time method & $5-50$ & $\begin{array}{c}0.000889 \\
\left(1.42 \times 10^{-5}\right)\end{array}$ & $\begin{array}{c}0.005426 \\
(0.000440)\end{array}$ & 0.9989 & 1.485 & 4.949 \\
\hline $\begin{array}{l}\text { 5- Imipramine } \mathrm{HCl} \\
\text { i-Slope method }\end{array}$ & $5-50$ & $\begin{array}{c}0.000291 \\
\left(626 \times 10^{-6}\right.\end{array}$ & -0.000350 & 0.9982 & 2.000 & 6.667 \\
\hline ii-Fixed time method & $5-50$ & $\begin{array}{c}0.008447 \\
(0.000180)\end{array}$ & $\begin{array}{l}-0.01000 \\
(0.005579)\end{array}$ & 0.9982 & 1.981 & 6.605 \\
\hline iii-Variable time methods & $5-50$ & $\begin{array}{c}0.001283 \\
\left(2.97 \times 10^{-5}\right)\end{array}$ & $\begin{array}{c}0.001159 \\
(0.000865)\end{array}$ & 0.9981 & 2.023 & 6.742 \\
\hline
\end{tabular}

LOD : Limit of detection

LOQ : Limit of quantitation

Table 6: Analysis of chlorpromazine $\mathrm{HCl}^{\circledR}$ in presence of some common additives using fixed time kinetic method.

\begin{tabular}{||l|c|c|}
\hline \multicolumn{1}{|c|}{ Ingredient } & Amount added & \% Recovery ${ }^{*} \pm$ S.D. \\
\hline 1- Starch & $100 \mathrm{mg}$ & $98.35 \pm 0.91$ \\
2- Sucrose & $100 \mathrm{mg}$ & $98.73 \pm 1.16$ \\
3- Glucose & $100 \mathrm{mg}$ & $97.85 \pm 1.06$ \\
4- Gum acacia & $20 \mathrm{mg}$ & $98.48 \pm 0.82$ \\
5- Lactose & $20 \mathrm{mg}$ & $98.35 \pm 1.05$ \\
6- Mg-stearate & $10 \mathrm{mg}$ & $97.7 \pm 1.44$ \\
7- Talc & $20 \mathrm{mg}$ & $98.22 \pm 1.16$ \\
\hline
\end{tabular}

*Average of four determinations

${ }^{\circledR}$ using $30 \mu \mathrm{g} / \mathrm{ml}$ chlorpromazine $\mathrm{HCl}$ 
Table 7: Determination of studied drugs in some pharmaceutical preparations using proposed and official methods.

\begin{tabular}{|c|c|c|c|c|}
\hline \multirow[b]{2}{*}{ Product } & \multirow{2}{*}{$\begin{array}{l}\text { Ingredient } \\
\text { (content, mg) }\end{array}$} & \multicolumn{3}{|c|}{$\%$ Recovery $^{*} \pm \mathrm{SD}$} \\
\hline & & Method A & Method B & $\begin{array}{l}\text { Official } \\
\text { method }\end{array}$ \\
\hline $\begin{array}{l}\text { 1- Halodol deconas } \\
{\text { (ampoules })^{\mathrm{a}}}\end{array}$ & $\begin{array}{l}\text { Haloperidol } \\
\quad(50 \mathrm{mg})\end{array}$ & $\begin{array}{c}99.16 \pm 1.05 \\
{ }^{* *} \mathrm{t}=1.6700, \mathrm{~F}=1.8420\end{array}$ & ----- & $100.14 \pm 0.77$ \\
\hline $\begin{array}{r}\text { 2- Safinace } \\
\text { (tablets) }^{\mathrm{a}} \\
\end{array}$ & $\begin{array}{l}\text { Haloperidol } \\
(5 \mathrm{mg})\end{array}$ & $\begin{array}{c}99.01 \pm 0.92 \\
\mathrm{t}=1.5376, \mathrm{~F}=1.1146\end{array}$ & ----- & $99.88 \pm 0.87$ \\
\hline $\begin{array}{l}\text { 3- Safinace } \\
{(\text { tablets })^{\mathrm{a}}}\end{array}$ & $\begin{array}{c}\text { Haloperidol } \\
(1.5 \mathrm{mg}) \\
\end{array}$ & $\begin{array}{c}98.98 \pm 1.00 \\
\mathrm{t}=2.219, \mathrm{~F}=1.6216\end{array}$ & ----- & $100.24 \pm 0.78$ \\
\hline $\begin{array}{l}\text { 4- Droperidol } \\
\text { (synthetic mix.) }^{* * * c} \text { c }\end{array}$ & $\begin{array}{c}\text { Droperidol } \\
(5 \mathrm{mg})\end{array}$ & $\begin{array}{c}99.01 \pm 0.92 \\
\mathrm{t}=0.032, \mathrm{~F}=1.0064\end{array}$ & ----- & $99.40 \pm 1.10$ \\
\hline 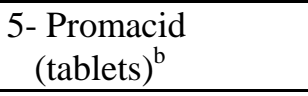 & $\begin{array}{l}\text { Chlorpromazine } \mathrm{HCl} \\
(100 \mathrm{mg})\end{array}$ & $\begin{array}{c}99.09 \pm 1.02 \\
\mathrm{t}=0.492, \mathrm{~F}=1.3796\end{array}$ & $\begin{array}{c}98.78 \pm 1.56 \\
\mathrm{t}=0.7617, \mathrm{~F}=3.196\end{array}$ & $99.38 \pm 0.87$ \\
\hline $\begin{array}{c}\text { 6- Neurazine } \\
\text { (tablets) }^{\mathrm{b}}\end{array}$ & $\begin{array}{c}\text { Chlorpromazine } \mathrm{HCl} \\
(100 \mathrm{mg})\end{array}$ & $\begin{array}{c}99.12 \pm 1.13 \\
\mathrm{t}=0.128, \mathrm{~F}=1.639\end{array}$ & $\begin{array}{c}98.88 \pm 1.55 \\
\mathrm{t}=0.4066, \mathrm{~F}=3.075\end{array}$ & $99.20 \pm 0.88$ \\
\hline $\begin{array}{l}\text { 7- Melleril retard } \\
\text { (tablets) }^{\mathrm{b}}\end{array}$ & $\begin{array}{c}\text { Thioridazine } \mathrm{HCl} \\
(30 \mathrm{mg})\end{array}$ & $\begin{array}{c}99.01 \pm 1.20 \\
\mathrm{t}=0.796, \mathrm{~F}=2.535 \\
\end{array}$ & $\begin{array}{c}98.64 \pm 1.59 \\
\mathrm{t}=1.1140, \mathrm{~F}=4.430\end{array}$ & $99.56 \pm 0.76$ \\
\hline 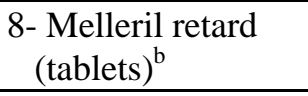 & $\begin{array}{l}\text { Thioridazine } \mathrm{HCl} \\
(200 \mathrm{mg})\end{array}$ & $\begin{array}{c}99.15 \pm 1.16 \\
\mathrm{t}=0.234, \mathrm{~F}=1.797\end{array}$ & $\begin{array}{c}98.64 \pm 1.54 \\
\mathrm{t}=0.8260, \mathrm{~F}=3.150\end{array}$ & $99.30 \pm 0.86$ \\
\hline $\begin{array}{l}\text { 8- Desipramine } \\
\text { (synthetic mix.) }^{* * * b} \text { b }\end{array}$ & $\begin{array}{c}\text { Desipramine } \mathrm{HCl} \\
(25 \mathrm{mg})\end{array}$ & $\begin{array}{c}99.28 \pm 1.10 \\
\mathrm{t}=0.893, \mathrm{~F}=1.760 \\
\end{array}$ & $\begin{array}{c}98.77 \pm 1.72 \\
\mathrm{t}=1.249, \mathrm{~F}=4.200\end{array}$ & $99.84 \pm 0.84$ \\
\hline $\begin{array}{l}\text { 10- Tofranil } \\
\text { (tablets) }^{\mathrm{b}}\end{array}$ & $\begin{array}{c}\text { Imipramine } \mathrm{HCl} \\
(25 \mathrm{mg})\end{array}$ & $\begin{array}{c}99.60 \pm 0.91 \\
\mathrm{t}=0.262, \mathrm{~F}=1.152\end{array}$ & $\begin{array}{c}99.78 \pm 1.86 \\
\mathrm{t}=0.357, \mathrm{~F}=4.820\end{array}$ & $99.46 \pm 0.85$ \\
\hline $\begin{array}{c}\text { 11- Supranil } \\
\text { (capsules) }^{\mathrm{b}}\end{array}$ & $\begin{array}{c}\text { Clomipramine } \mathrm{HCl} \\
(50 \mathrm{mg})\end{array}$ & $\begin{array}{c}98.94 \pm 0.94 \\
\mathrm{t}=0.626, \mathrm{~F}=1.319\end{array}$ & $\begin{array}{c}98.28 \pm 1.70 \\
\mathrm{t}=1.193, \mathrm{~F}=4.320\end{array}$ & $99.30 \pm 0.82$ \\
\hline $\begin{array}{l}\text { 12- Supranil } \\
\left(^{(\text {capsules })^{b}}\right.\end{array}$ & $\begin{array}{c}\text { Clomipramine } \mathrm{HCl} \\
(25 \mathrm{mg})\end{array}$ & $\begin{array}{c}99.13 \pm 1.03 \\
\mathrm{t}=0.969, \mathrm{~F}=1.163\end{array}$ & $\begin{array}{l}100.70 \pm 1.45 \\
\mathrm{t}= \\
\mathrm{y}\end{array}$ & $99.74 \pm 0.96$ \\
\hline $\begin{array}{l}\text { 13- Anafranil SR } \\
\text { (tablets) }^{\mathrm{b}}\end{array}$ & $\begin{array}{c}\text { Clomipramine } \mathrm{HCl} \\
(75 \mathrm{mg})\end{array}$ & $\begin{array}{c}99.69 \pm 1.045 \\
\mathrm{t}=0.533, \mathrm{~F}=1.274\end{array}$ & $\begin{array}{c}99.50 \pm 1.71 \\
\mathrm{t}=0.244, \mathrm{~F}=4.580\end{array}$ & $99.40 \pm 0.89$ \\
\hline $\begin{array}{c}\text { 14- Anafranil } \\
\text { (tablets) }^{\mathrm{b}}\end{array}$ & $\begin{array}{c}\text { Clomipramine } \mathrm{HCl} \\
(25 \mathrm{mg})\end{array}$ & $\begin{array}{c}99.16 \pm 0.99 \\
\mathrm{t}=0.398, \mathrm{~F}=1.231\end{array}$ & $\begin{array}{c}99.90 \pm 1.30 \\
\mathrm{t}=0.720, \mathrm{~F}=2.160\end{array}$ & $99.29 \pm 0.80$ \\
\hline
\end{tabular}

Method A Extractive spectrophotometric method

Method B Fixed time kinetic method

*Average of five determinations

${ }^{* * *}$ Theoritical values at $95 \%$ confidence limit $(\mathrm{t}=2.306, \mathrm{~F}=6.388)$

**** Laboratory prepared synthetic mixture

${ }^{\mathrm{a}}$ According to USP $1990 \quad{ }^{\mathrm{b}}$ According to BP 1998

${ }^{\mathrm{c}}$ According to Ref. [8]

\section{REFERENCES}

1- Goodman and Gilman's, "The Pharmacological Basis of Therapeutics", $9^{\text {th }}$ ed., MC Graw-Hill, New York p. 383 (1996).

2- J. M. Garciafraga, A. I. Jimenz Abizanda, F. Jimenez Moreno and F. Arias, J. Pharm. Biomed. Anal., 9, 105-115 (1991).
3- S. A. Hussein, M. E. El-Kommos, H. Y. Hassan, A. M. I. Mohamed, Talanta, 36, 941-944 (1989).

4- H. A. Mohamed, H. Y. Hassan, A. M. I. Mohamed and S. A. Hussein, Anal. Lett., 25, 63-71 (1992).

5- S. A. Hussein and A. M. I. Mohamed, Talanta, 36, 1147-1149 (1989). 
6- P. A. Bakurdesai and A. V. Kasture, Indian Drugs, 31, 219-221 (1994). Through Anal. Abstr., 57, 1 G86 (1995).

7- G. Misztal, Farm. Po., 44, 206-208 (1988). Through Anal. Abstr., 51, 1E48 (1989).

8- H. F. Askal, Talanta, 44, 1749-1755 (1997).

9- G. R. Rao, S. Raghuveer, Indian Drugs, 19, 408-409 (1982). Through Anal. Abstr., 45, 2E48 (1983).

10- M. M. Kucher and V. P. Kramarenko, Farm. Zh., 6, 67-68 (1985). Through Anal. Abstr., 48, 4E52 (1986).

11- M. M. Kucher and V. P. Kramarenko, Farm. Zh., 5, 72-73 (1984). Through Anal. Abstr., 47, 6E48 (1985).

12- K. Kitamura, T. Goto and T. Kitade, Talanta, 46, 1433-1438 (1998).

13- K. Kitamura, H. Mano, Y. Tadokoro, K. Tsuruta and S. Kitagowa, Frensenius J. Anal. Chem., 358, 509-513 (1997).

14- M. M. El-Kerdawy, S. M. Hassan and S. M. El-Ashry, Mikrochim Acta, 108, 323328 (1992).

15- A. F. Youssef, S. R. ElShabouri, F. A. Mohamed and A. M. I. Rageh, J. Assoc. Off. Anal. Chem., 69, 513-518 (1986).

16- S. M. Hassan, F. Belal, F. Ibrahim and F. A. Aly, Anal. Lett., 22, 1485-1498 (1989).

17- T. S. Al-Ghabsha, S. K. Ibrahim and M. Q. Al-Abachi, Microchem. J., 28, 501-504 (1983).

18- M. Tarasiewicz and L. Kuymicka, Anal. Lett., 29, 929-936 (1996).

19- B. Starczewska and J. Karpinska, Anal. Lett., 29, 2475-2486 (1996).

20- J. Karpinska, Anal. Lett., 33, 1555-1566 (2000).

21- K. Basavaiah and G. Krishnamurthy, Talanta, 46, 665-670 (1998).

22- M. Rizk, N. A. Zakhari, F. Ibrahim and M. I. Walash, Mikrochim Acta, 355-363 (1989).

23- A. M. Horria, H. R. Ibrahim, Bull. Pharm. Sci., 22, 191-196 (1999).

24- H. L. Rau, A. R. Aroor and P. G. Rao, Indian J. Pharm. Sci., 53, 31-37 (1991).

25- W. Baeyens and P. De Moerlosser, Pharmazie, 32, 764-770 (1977).

26- F. A. Mohamed, Anal. Lett., 28, 24912497 (1995).
27- J. Martinez-catalayud and C. GomezBenito, Anal. Chim. Acta, 256, 105-112 (1992).

28- D. Chen, A. Rios, M. D. Luque-de Castro and M. Valcarcel, Talanta, 38, 1227-1232 (1991).

29- M. C. Gutierrez, A. Gomez-Hens, D. Perez-Bendito, Anal. Lett., 20, 1847-1852 (1987).

30- M. Gajewska, J. Iliaszenko, M. Sokolowska and M. Muszynka, Acta Pol. Pharm., 44, 17-20 (1992).

31- M. P. San Andres,D. Sililia, S. Rubio and D. Perez-Bendito, J. Pharm. Sci., 87, 821826 (1998).

32- M. I. Walash, M. Rizk, A.M. Abou-ouf and F. Belal, Analyst, 108, 626-632 (1983).

33- E. P. Diamandis and T. K. Christopoulos, Anal. Chim. Acta, 152, 281-285 (1983).

34- N. A. Zakhari and K. A. Kovar, J. Assoc. Off. Anal. Chem., 69, 620-625 (1986).

35- V. V. Cosofret and R. B. Buck, Analyst, 109, 1321-1327 (1984).

36- K. Kadej, A. Parczewsk and M. Kala, Mikrochim Acta, 129, 121-126 (1998).

37- X. P. Lee, T. Kumazawa, K. Sato and O. Zuzuki, J. Chromatogr. Sci., 35, 302-308 (1997).

38- T. W. Ryan, J. Liq. Chromatogr., 16, 1545-1560 (1993).

39- S. Bouquet, S. Guyon, G. Chapeler, G.M.C. Perouit and D. Barthes, J. Liq. Chromatogr., 15, 1993-2001 (1992).

40- S. M. Wu, W. K. Ko, H. L. Wu and S. H. Chen, J. Chromatogr., 846, 239-243 (1999).

41- M. Aravagiri, S. R. Marder, T. Vanputten and B.D. Marshall, Chromatogr. B., Biomed. Appl., 656, 373-381 (1994).

42- G. T. Vatassey, L. A. Holdes and M. W. Dysken, J. Anal. Toxic., 17, 304-306 (1993).

43- M. El-Sayed, S. H. Khidr and E. M. Nlazy, J. Chromatogr. Related Tech., 19, 125-134 (1996).

44- H. J. Keukens and M. M. L. Aerts, J. Chromatogr., 464, 149-155 (1989).

45- G. Tamai, M. Yoshida and H. Imai, J. Chrom. Biomed. Appl., 67, 163-70 (1987).

46- L. F. S. Chagonda and J. S. Millership, Analyst, 113, 233-240 (1988). 
47- K. K. E., Johansen, J. Pharm. Biomed. Anal., 16, 1159-1169 (1998).

48- R. Theurillat and R.W. Thorman, J. Pharm. Biomed. Anal., 18, 751-760 (1998).

49- J. Karpinska, A. Kojlo, A. Grudniewska and H. Puzanowska-Tarasiewicz, Pharmazie, 51, 950-954 (1996).

50- M. Polasek, J. Dolejsova and R. Karlicek, Pharmazie, 53, 168-172 (1998).

51- D. Chen, A. Rios, M. D. Luque de Castro and M. Valcarcel, Talanta, 38, 1227-1233 (1991).

52- T. Perez-Ruiz, C. Martinez-Lezano, A. Sanz and C. Alonso, Talanta, 41, 15231527 (1994).

53- J. L. Lopaz-Paz and A. Townshend, Anal. Commun., 33, 31-33 (1996).

54- M.J. Hursting, G. Clark, S.J. Miller and K.E. Opheim, Clin. Chem., 38, 2468-2472 (1992). Through Anal. Abstr., 55, 8G133 (1993).

55- G. M. Meenan, S. Barlotto and M. H. N. Lehrer, J. Anal. Toxico., 14, 273-276 (1990). Through Anal. Abstr., 54, 1G41 (1992).
56- R. Krulik, J. Exner, K. Fuksova, D. Pichova and D. Beitlova, J. Eur. J. Clin. Chem. Clin. Biochem., 29, 827-832 (1991).

57- I. Biryol, B. Uslu and Z. Kucukyavuz, J. Pharm. Biomed. Anal., 15, 371-381 (1996).

58- M. Khodari, A. Ali and N. A. El-Maali, Anal. Lett., 26, 1099-1104 (1993).

59- G. M. Greenway and S. J. L. Dolman, Analyst, 124, 759-762 (1999).

60- Y. Y. Xue, Y. H. He and J. R. Lu, Fenxi Shiyanshi, 18, 49-51 (1999). Through Anal. Abstr., 61, 9G74 (1999).

61- T. Fujii, Y. Kurlhara, H. Arimoto and Y. Mitsutsuka, Anal. Chem., 66, 1884-1889 (1994).

62- F. A. Mohamed, A. M. I. Mohamed, H. A. Mohamed and S. A. Hussein, Talanta, 43, 1931-1939 (1996).

63- M. Pesez, J. Bartos, Colorimetric and fluorimetric analysis of organic compounds and drugs, M. Dekker, New York, pp. 623-632 (1974).

64- J. B. Hanbone, T. J. Mabry and H. Habry, The flavonoids, Champan and Hall, London, p. 311 (1975). 